\title{
Suspended sediment transport diversity in river catchments following the 2014 phreatic eruption at Ontake Volcano, Japan
}

\author{
Kyoko S. Kataoka ${ }^{*}$, Takane Matsumoto ${ }^{1}$, Takeshi Saito ${ }^{2}$, Yoshitaka Nagahashi ${ }^{3}$ and Tsutomu lyobe ${ }^{4}$
}

\begin{abstract}
The present contribution investigates the temporal changes in volcaniclastic sediment transport over the 2-year period after the 2014 eruption of Ontake Volcano in two small drainage basins where increased turbidity was observed immediately after the eruption. Two similar-sized catchments on the southern flank of the volcano, the Akagawa River $\left(\sim 4.4 \mathrm{~km}^{2}\right)$ and the Shirakawa River $\left(\sim 2.9 \mathrm{~km}^{2}\right)$ catchments, exhibited contrasting sediment delivery patterns and river water characteristics such as acidity and electric conductivity (EC). Increased turbidity, a high rate of suspended sediment supply, and elevated EC values were observed only in the Akagawa River, which hosts volcanic vents in its proximal part. The mineral assemblages and chemical characteristics of suspended sediment from the Akagawa River clearly indicate that the turbidity was derived from the erosion and reworking of primary eruptive material and lahar deposits. Previous airborne and remote surveys suggested the presence of primary ashfall and pyroclastic density currents in the upslope areas and valley heads of both the Akagawa and Shirakawa rivers. However, the river water characteristics and sediment transportation data of the present study clarify that the initial volcanic disturbance of the Shirakawa catchment was minor and limited. The influence of volcanic disturbance on the Akagawa River catchment continued for at least 10 months after the eruption and was also observed for an additional 9 months until the end of the snowmelt season in 2016. In the Akagawa River valley, two post-eruptive lahars that occurred during a 7-month period may have enhanced the removal of volcaniclastic deposits, and this remobilization may have resulted in diminished sediment delivery in the river after the lahar events. The results of this study provide information about the timing of the decline of suspended sediment delivery associated with small-scale eruptive activity, and such information may prove useful for evaluating the effects of other eruptions similar in size and character to the 2014 Ontake eruption. In addition, the approach adopted for monitoring rivers at downstream sites is clearly of utility for evaluating primary pyroclastic deposition and volcanic disturbance near inaccessible vent areas.
\end{abstract}

Keywords: Ontake Volcano, 2014 eruption, Phreatic eruption, Suspended sediment supply, Volcanic disturbance, Water characteristics

\section{Introduction}

Explosive volcanic eruptions and their products can physically and chemically affect rivers in the vicinity of volcanoes. Increased turbidity and suspended sediment transport are commonly observed following an eruption (Blong 1984; Stewart et al. 2006), with the increased

\footnotetext{
*Correspondence: kataoka@gs.niigata-u.ac.jp

${ }^{1}$ Research Institute for Natural Hazards and Disaster Recovery, Niigata

University, Ikarashi 2-8050, Nishi-ku, Niigata 950-2181, Japan

Full list of author information is available at the end of the article
}

sediment supply to a river system being caused mainly by the erosion and remobilization of new, loosely packed eruptive material deposited upstream of the catchment. Unseen but important impacts of volcanic eruptions on rivers are the alteration of water characteristics such as increased acidity, changes in electric conductivity (EC), and the occurrence of other soluble contaminants (Kristmannsdóttir et al. 1999; Stewart et al. 2006). Physically and chemically contaminated river water following an explosive eruption is sometimes lethal to riverine biota and can affect water supply with respect to 
drinking water quality and irrigation use. Therefore, the monitoring of temporal changes in the supply of volcanic suspended sediment, turbidity, and other river water characteristics following an eruption and the understanding of the timing of river water recovery to background (i.e., pre-eruption) levels are important for quantifying the effects of eruptions as well as for predicting and preparing for the aftermaths of future eruptions.

The duration of increased sediment supply relative to the background level through a river system can persist for years to decades or more depending on the size and character of an eruption and the hydro-geomorphological characteristics of the area (Major et al. 2000; Major 2004; Major and Yamakoshi 2005; Gran et al. 2011; Pierson and Major 2014). Even a relatively small-scale magmatic eruption, such as an event with a Volcanic Explosivity Index (VEI) value of 3 (Newhall and Self 1982), can result in a subsequent high sediment discharge, as observed for the 1990-1995 eruption episode at Mt. Unzen and the 2000 eruption at Miyakejima (Yamakoshi et al. 2005; Ogawa et al. 2007). At these volcanoes, which are located in temperate climate conditions, a temporal decline in excess sediment delivery was caused by permeability changes after remobilization of the ash deposits that covered slopes and recovery of vegetation (Ogawa et al. 2007) as well as by shortages of erodible material in river valleys resulting from reworking processes (Yamakoshi et al. 2005).

Following the 2014 phreatic eruption at Ontake Volcano (VEI =1-2: Maeno et al. 2016), which resulted in 63 casualties from primary ejecta at the summit of the volcano, turbid river water in the Nigorigawa and downstream Otakigawa rivers (Fig. 1a) was initially reported immediately after the eruption (e.g., Oikawa et al. 2016). However, there have been no further studies or reports of post-eruption temporal changes in the water turbidity and other characteristics following the Ontake event. The presence of turbid water implies an increased supply of suspended sediment derived from volcanic ash following the eruption. Local residents in the downstream catchment areas were anxious about increased turbidity and changes in acidity immediately after the eruption, although there was no report of severe impacts causing problems in terms of the contamination of water for drinking and irrigation.

The aim of this study was to understand the length of time that a small eruption could affect river water, focusing on the temporal changes in suspended sediment transport, turbidity, $\mathrm{pH}$ (acidity), and EC in the catchment areas of the Akagawa and Shirakawa rivers on the southern flank of Ontake Volcano (Fig. 1a). In addition, possible causes of the different impacts on the two river catchments and of the temporal changes in the amounts of suspended sediment in the 2-year period following the 2014 eruption are discussed to evaluate the volcanic disturbance in inaccessible vent-proximal areas.

\section{Regional setting and description of the $\mathbf{2 0 1 4}$ eruption \\ Physiography and regional climate}

Ontake Volcano $\left(35^{\circ} 53^{\prime} 34^{\prime \prime} \mathrm{N}, 137^{\circ} 28^{\prime} 49^{\prime \prime} \mathrm{E}\right)$ is located on the island of Honshu at the border of Nagano and Gifu prefectures. The summit of the volcano is at an altitude of $3067 \mathrm{~m}$, and the Nigorigawa River catchment occupies the high-elevation southern flank of the volcano. This catchment includes the Akagawa and Shirakawa rivers, which flow parallel to each other. The vents of the 2014 eruption are known locally as the Jigokudani vents and are situated at the head of the Akagawa River valley (Fig. 1a). The catchment area of the Akagawa River upstream of the observation point (Fig. 1a) is about $4.4 \mathrm{~km}^{2}$, whereas that of the Shirakawa River is $2.9 \mathrm{~km}^{2}$.

Seasonal snow cover on Ontake Volcano is typically present from November to May under the temperate climatic conditions of the area. After the September 2014 eruption at Ontake, 2 years of meteorological observations on the southeastern slope at an altitude of $2190 \mathrm{~m}$ yielded data on hourly rainfall and the hourly rate of snowmelt (Kataoka et al. 2018).

\section{The inferred volcanic disturbance caused by the 2014 eruption}

The phreatic eruption of Ontake Volcano on 27 September 2014 (11:52 a.m. Japan time) ejected eruptive material with a volume of $0.7-1.3 \times 10^{6} \mathrm{~m}^{3}(\mathrm{VEI}=1-2$ : Maeno et al. 2016). Ashfall deposits were concentrated around the vents and covered areas mostly to the east of the summit (Oikawa et al. 2014; Maeno et al. 2016; Takarada et al. 2016). Thin ashfall deposits on the southern slope were also observed by an airborne survey. The ashfall distribution (Oikawa et al. 2014; Takarada et al. 2016) suggests that the proximal catchments of the Akagawa and Shirakawa rivers received about $2 \times 10^{5} \mathrm{~m}^{3}$ and $2 \times 10^{3} \mathrm{~m}^{3}$ of ashfall, respectively (Fig. 1a). Airborne survey and remote camera observations show that pyroclastic density currents flowed on the southern and western slopes of the volcano (Oikawa et al. 2014; Yamamoto 2014; Kaneko et al. 2016; Maeno et al. 2016; Fig. 1a). However, the actual thicknesses and depositional facies of pyroclastic density current deposits confined to the upstream parts of the Akagawa and Shirakawa valleys as well as the initial volcanic disturbance in these proximal areas are still unknown because of a lack of ground-truth surveys. 


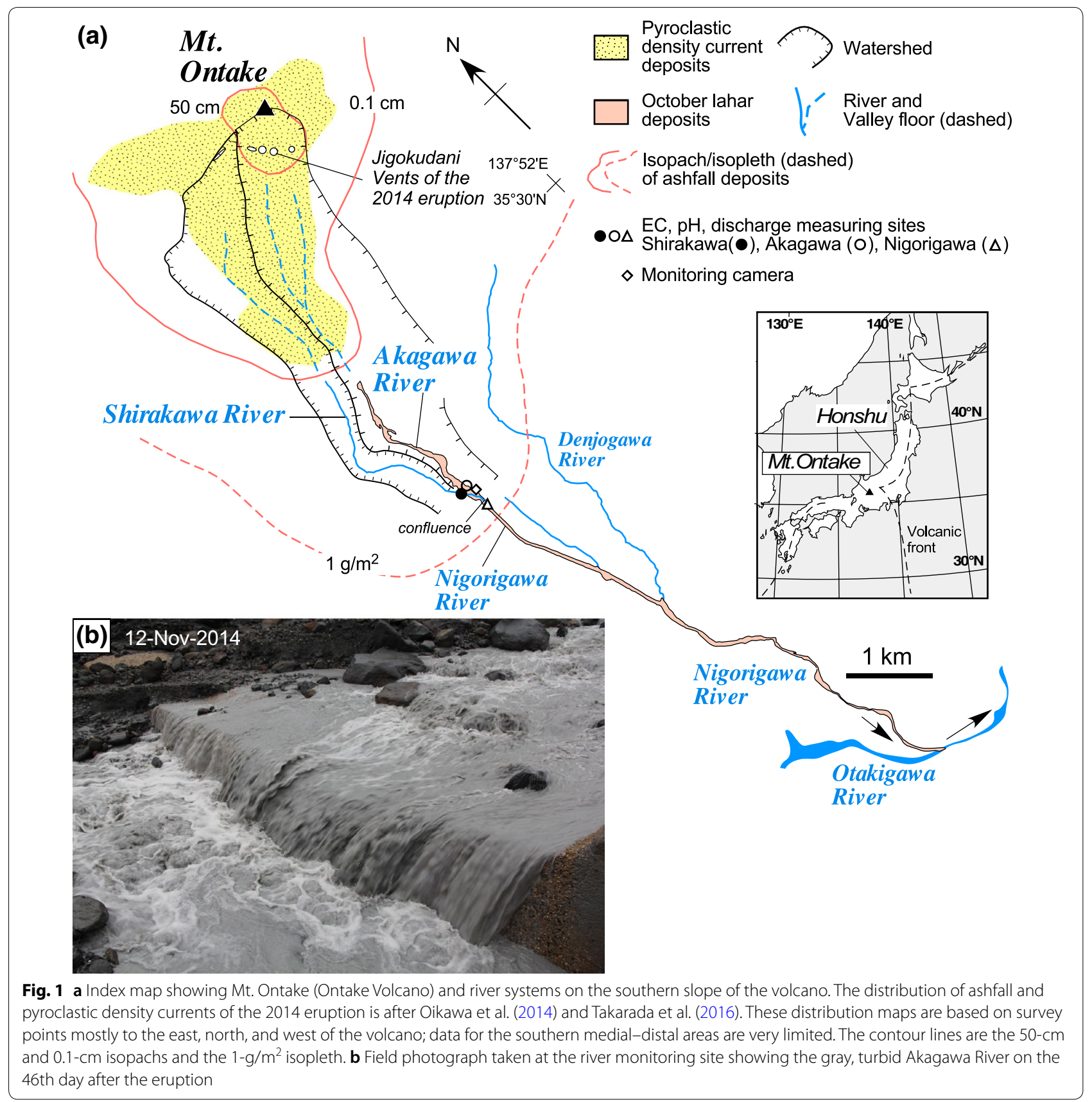

Three lahars associated with the eruption occurred in the Akagawa and Nigorigawa rivers: (1) An eruptiontriggered lahar occurred on 27 September 2014 and left thin mud-slurry deposits up to $5 \mathrm{~km}$ downstream of the Jigokudani vents (Sasaki et al. 2016). (2) A raintriggered lahar on 5 October was generated by the second rainstorm after the eruption (the cumulative rainfall until lahar generation was $47.5 \mathrm{~mm}$ ) and deposited clayrich debris flow deposits with a volume of $2.9 \times 10^{5} \mathrm{~m}^{3}$
(Kataoka et al. 2018). The deposits from this lahar contain high levels of clay (10-20 wt\% of clay in the matrix) and notably contain high amounts of sulfur (10-14 wt\%) in terms of bulk chemistry. The 5 October lahar traveled $11 \mathrm{~km}$ downstream and reached the confluence with the Otakigawa River (Fig. 1a). (3) A rain-on-snow-induced lahar on 20 April 2015 was triggered by an extreme rainstorm and associated snowmelt of about $100 \mathrm{~mm}$ water equivalent (a total input of $332 \mathrm{~mm}$ over the $13 \mathrm{~h}$ prior to this lahar; Kataoka et al. 2018). The water-rich erosional 
lahar flow left sandy and gravelly hyperconcentrated flow deposits and normal streamflow (upper flow regime) deposits as far as the confluence with the Otakigawa River. In contrast, there were no lahar deposits along the Shirakawa River. No further lahars were detected by camera monitoring or wire sensors after the rain-onsnow lahar of 20 April until the end of the observation period (at least until the end of 2016; Kataoka et al. 2018).

\section{Methodology}

\section{Measurement of river water characteristics}

Water characteristics and suspended sediment transport following the September 2014 eruption were examined for the Akagawa and Shirakawa rivers for 2 years (Table 1). Data for the Nigorigawa River, obtained immediately downstream from the confluence of the Akagawa and Shirakawa rivers, were used as reference values. On-site measurements of $\mathrm{pH}$ and EC (as specific conductivity at $25^{\circ} \mathrm{C}$ ) were taken using a hand-held measuring instrument (WM-32EP, DDK-TOA Corp., Japan). To measure suspended sediment concentration, river water was sampled in the field and filtered in the laboratory at Niigata University using filters with pore size $=0.5 \mu \mathrm{m}$. Coarse particles $(>2 \mathrm{~mm}$ in size) were removed with a sieve before weighing the sediment samples, as coarser particles transported by saltation were occasionally included in samples when flow discharge was high. For evaluating turbidity, we performed a visual assessment in the field using the following classification: (1) turbid: gray to blue-gray-colored water, the riverbed cannot be seen owing to turbidity (Fig. 1b); (2) slightly turbid: light gray, semitransparent water, some riverbed deposits can be seen; and (3) clear: transparent water. Flow discharge $\left(\mathrm{m}^{3} / \mathrm{s}\right)$ was estimated on the basis of direct measurement of flow depth, width, and velocity in the rivers.

Images of the riverbed were captured at 10-min intervals by a time-lapse camera deployed along the Akagawa River at our river observation point (Fig. 1a). The camera also recorded water levels and turbidity at this site (Additional file 1). This enabled us to describe and evaluate the lahar events and the cause(s) of the changes in discharge and sediment transport resulting from snowmelt and/or rainstorm events.

\section{Geochemical and mineralogical analyses of suspended sediment}

The chemical characteristics and mineral assemblages of suspended sediment are important for determining the origin of the transported sediments. For this purpose, X-ray fluorescence (XRF) analysis (Rigaku RIX2000 at Fukushima University) and X-ray diffraction (XRD) analysis (Rigaku Ultima IV at Niigata University) were performed on samples of filtered suspended sediments, mainly from the Akagawa River, where high levels of suspended sediment were observed after the eruption (Fig. 1b). The measurement conditions and results are provided in Tables 2 and 3.

\section{Characteristics of water and suspended sediment in the Akagawa and Shirakawa rivers following the 2014 eruption}

Water characteristics in the Akagawa and Shirakawa rivers show variations in $\mathrm{pH}, \mathrm{EC}$, suspended sediment concentration, and turbidity (Table 1 and Fig. 2). These characteristics can be affected by rates of flow discharge; therefore, measured discharge and 48-h total water input (including snowmelt water) on the observation dates (Tanohara meteorological observation site: Kataoka et al. 2018) are also provided in Table 1.

For the period from November 2014 to July 2016, the Akagawa River exhibited high acidity (pH: 2.6-3.6), whereas the Shirakawa River was moderate to acid (pH: 4.5-5.2). EC was always stable at around $30 \mathrm{mS} / \mathrm{m}$ in the Shirakawa River, and the suspended sediment concentration was relatively low from immediately after the eruption to 700 days after the event (Fig. 2a, b). In contrast, the Akagawa River exhibited different sediment transport and water characteristics and was affected by the 2014 eruption for a longer time than the Shirakawa River (Fig. 2a, b, and Table 1). After the eruption until July 2015, the river was visibly turbid and had higher sediment concentrations, occasionally with EC $>200 \mathrm{mS} / \mathrm{m}$ and even sometimes without major water input (Figs. 1b, $2 \mathrm{a}, \mathrm{b}$, and Table 1). Thereafter, the values of EC, suspended sediment concentration, and turbidity tended to decline (Fig. 2a, b), although they varied during the snowmelt season (April-May) and with occasional rain. During the snowmelt seasons of April 2015 and April 2016, conspicuous diurnal changes in flow discharge and turbidity were observed in the field (Additional file 1, Table 1, and Fig. 2a, b). In the mornings, the river had a low water level and was visibly clear, but increasing discharge and turbidity occurred during the afternoons (about 2-5 p.m., Additional file 1).

The XRF results for filtered suspended sediment indicate very high sulfur contents in samples from the Akagawa River (7.8-12 wt\%; Table 2). The mineral assemblage of the suspended sediments from the Akagawa River identified by XRD consists of quartz, plagioclase, cristobalite, pyrite, gypsum, anhydrite, alunite, pyrophyllite, smectite, illite, kaolin group minerals $(7 \AA)$, and chlorite (Table 3). Sediments from the Shirakawa River have a different mineral assemblage, consisting of quartz, plagioclase, cristobalite, anhydrite, alunite, smectite, and 


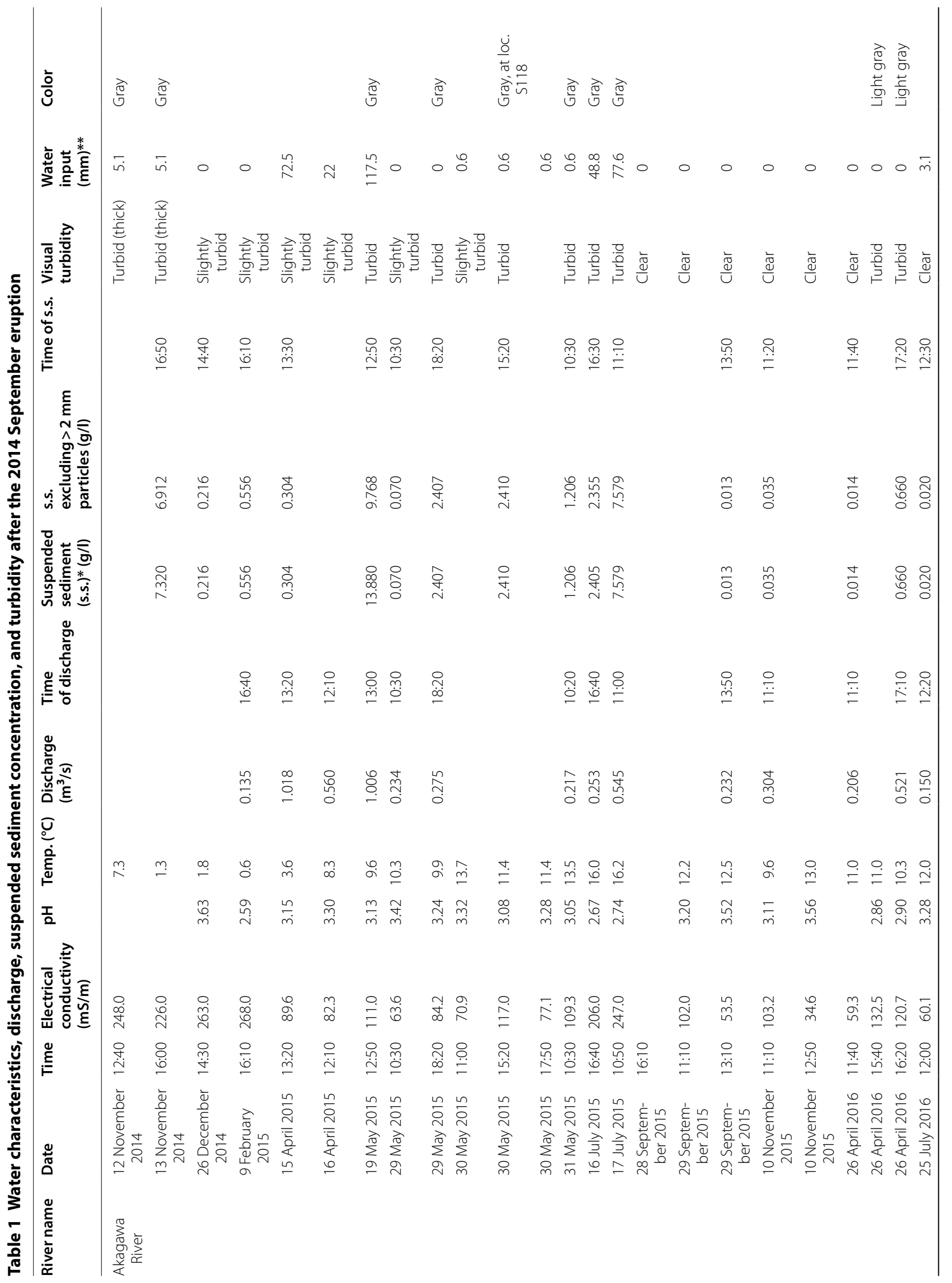




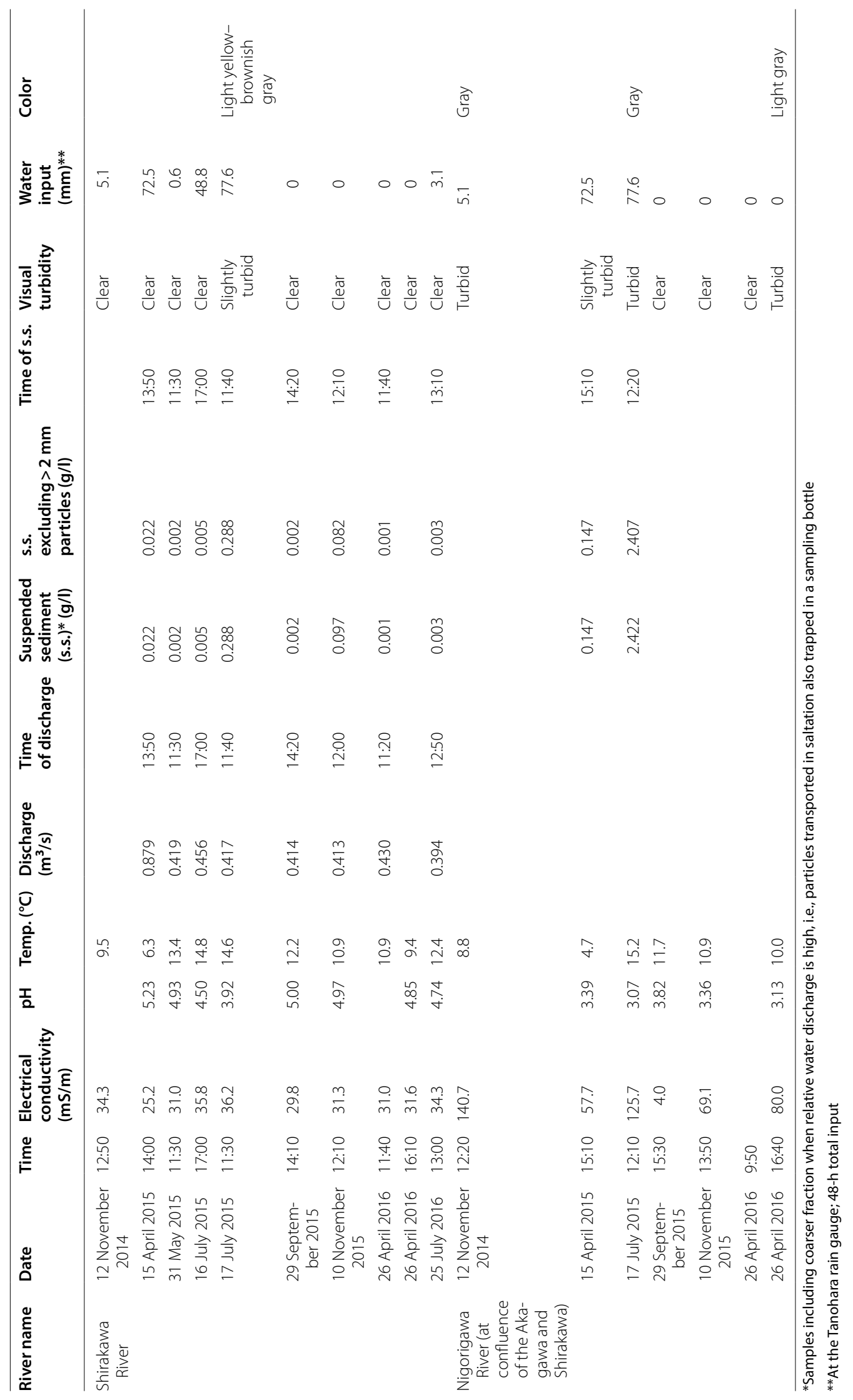


Table 2 XRF results for filtered suspended sediment from the Akagawa River

\begin{tabular}{|c|c|c|c|c|c|c|c|c|c|c|c|c|}
\hline Sampling date & $\mathrm{SiO}_{2}(\mathrm{wt} \%)$ & $\mathrm{TiO}_{2}$ & $\mathrm{Al}_{2} \mathrm{O}_{3}$ & $\mathrm{Fe}_{2} \mathrm{O}_{3}{ }^{*}$ & $\mathrm{MnO}$ & $\mathrm{MgO}$ & $\mathrm{CaO}$ & $\mathrm{Na}_{2} \mathrm{O}$ & $\mathrm{K}_{2} \mathrm{O}$ & $\mathrm{P}_{2} \mathrm{O}_{5}$ & $\mathrm{SO}_{3}{ }^{* *}$ & Total \\
\hline $6: 50 \mathrm{pm}(n=9)$ & 55.17 & 1.08 & 21.04 & 6.22 & 0.09 & 0.33 & & 0.28 & 2.31 & 0.33 & 11.99 & . \\
\hline 26-Dec-2014-14:40 pm $(n=1)$ & 57.73 & 0.93 & 20.74 & 2.43 & 0.02 & 0.34 & 1.29 & 0.30 & 7.79 & 0.65 & 7.79 & 100.00 \\
\hline 9-Feb-2015-16:10 pm $(n=2)$ & 56.55 & 1.23 & 19.53 & 5.75 & 0.03 & 0.31 & 1.58 & 0.30 & 2.38 & 0.48 & 11.87 & 100.00 \\
\hline
\end{tabular}

Analyzed by Rigaku RIX2000 at Fukushima University. The accelerating voltage and tube current were $50 \mathrm{kV}$ and $50 \mathrm{~mA}$, respectively. Data for major element and total sulfur $\left(\mathrm{as}_{3}\right.$ ) content are semiquantitative by FP (fundamental parameter) method with a standard-less technique (Takase and Nagahashi 2007)

*Total iron oxide as $\mathrm{Fe}_{2} \mathrm{O}_{3}$

**Total sulfur as $\mathrm{SO}_{3}$

Table 3 Mineral assemblages of filtered suspended sediment from the Akagawa and Shirakawa rivers identified using XRD

\begin{tabular}{|c|c|c|c|c|c|c|c|c|c|c|c|c|}
\hline & Qz & PI & Crs & Py & Gp & Anh & Alu & Prl & Sme & Ilt & KIn & Chl \\
\hline \multicolumn{13}{|l|}{ Akagawa River } \\
\hline 13 November 2014, 16:50 pm (ID: F8) & + & + & + & + & + & + & + & & + & + & + & \\
\hline 9 February 2015, 16:10 pm (ID: F13-14) & + & + & + & + & & + & + & & + & & + & \\
\hline 17 July 2015, 11:10 am (ID: F134) & + & + & + & + & & + & + & + & + & & + & + \\
\hline 26 April 2016, 17:20 pm (ID: F142) & + & + & + & + & + & + & + & + & + & & + & \\
\hline \multicolumn{13}{|l|}{ Shirakawa River } \\
\hline 17 July 2015, $11: 40$ am (ID: F137) & + & + & + & & & + & + & & + & & + & \\
\hline
\end{tabular}

Abbreviations for minerals: Qz quartz, PI plagioclase, Crs cristobalite, Py pyrite, Gp gypsum, Anh anhydrite, Alu alunite, Prl pyrophyllite, Sme smectite, Ilt illite, KIn kaolin group minerals (7A), Chl chlorite

Analyzed by Rigaku Ultima IV at Niigata University. Measurement conditions were of CuKa radiation, $40 \mathrm{kV}$ and $40 \mathrm{~mA}$, and scanning speed of $2^{\circ}$ per minute. Samples were measured as bulk, oriented, and heated at $400{ }^{\circ} \mathrm{C}$ and $550^{\circ} \mathrm{C}$ conditions and were also treated with ethylene glycol to identify the minerals overlapping in certain cell parameters

kaolin group minerals (7 ̊̊). Pyrite, gypsum, pyrophyllite, illite, and chlorite were not detected.

\section{Discussion}

\section{The source of suspended sediment in the Akagawa River}

The mineral assemblages of suspended sediment samples in the Akagawa River are marked by the common presence of pyrite and other sulfate mineral grains (Table 3). The presence of pyrite is diagnostic of the 2014 Ontake deposits (Minami et al. 2016; Kataoka et al. 2018). Pyrophyllite was detected in minor amounts in the Akagawa River samples. Pyrophyllite is a common product of hydrothermal alteration (1-2 km depth) and has been recognized in the 2014 eruptive and October lahar deposits (Minami et al. 2016; Kataoka et al. 2018). The presence of these minerals confirms that suspended sediment in the Akagawa River was derived from the erosion and reworking of the 2014 eruptive material and lahar deposits.

The high sulfur content of suspended sediment from the Akagawa River (8-12 wt\%; Table 2) is related to the reworking of the September 2014 eruptive deposits (14 wt\%; Kataoka et al. 2018) and of the 2014 October lahar deposits (10-14 wt\% in the matrix; Kataoka et al. 2018), whereas pyrite and pyrophyllite grains were not present in suspended sediment from the Shirakawa River. This finding suggests that the reworking of eruptive deposits in the Shirakawa River drainage was limited and that the mineral composition of the suspended sediment reflects background levels of sediment transport.

Oikawa et al. (2016) reported the occurrence of muddy (i.e., turbid) water in the Nigorigawa River (downstream of the Akagawa River) between November 2014 and July 2015. Those authors suggested that the flow originated from ongoing muddy outflow from the eruptive vents after the eruption without any direct observation or evidence of new mud slurries being expelled from the vents, despite the main eruption period having ended in September 2014. However, that was a misinterpretation; instead, the turbidity was indeed derived from erosion and reworking of eruption and lahar deposits, as the high turbidity and suspended sediment concentration were mostly related to high water input and discharge (Table 2). In addition, the camera record from the snowmelt season at the Akagawa River (Additional file 1) clearly shows that diurnal fluctuations in turbidity and sediment discharge were repeatedly observed at a similar time of day, with increased turbidity and a high water discharge between 2 and 5 p.m. Therefore, sediment 


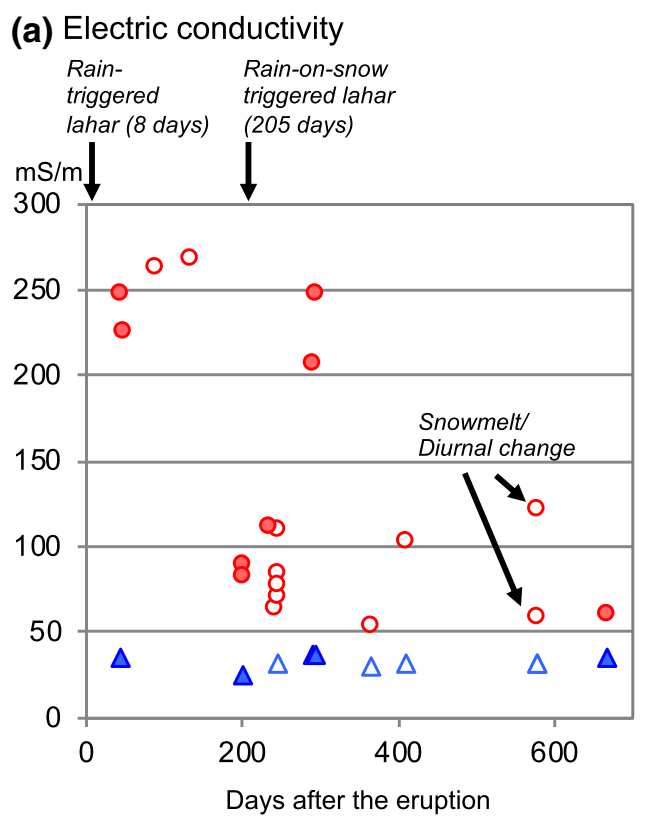

(a) Electric conductivity triggered lahar

Akagawa River 48hrs input

○ 0-1 mm $0>1 \mathrm{~mm}$ (rain) (b) Suspended sediment concentration

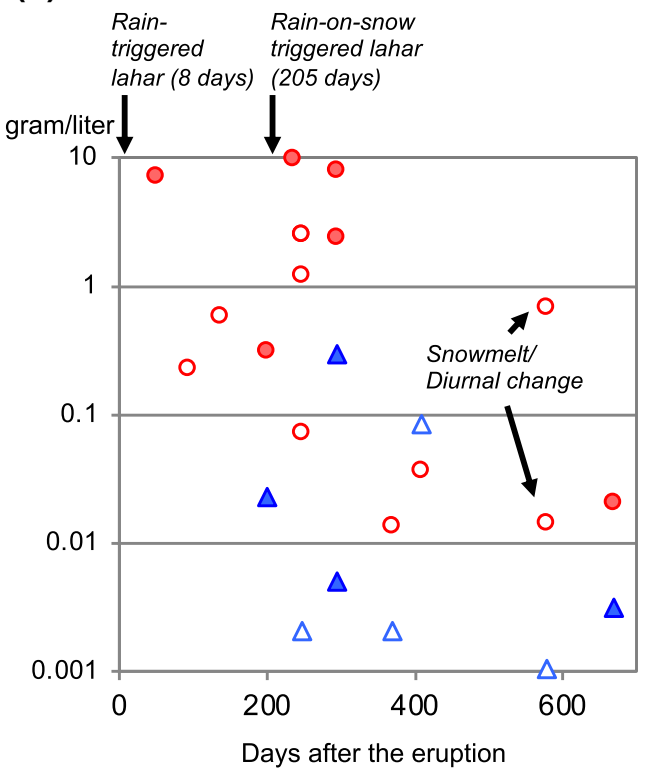

Shirakawa River 48hrs input

$\Delta$ 0-1 $\mathrm{mm} \quad \Delta>1 \mathrm{~mm}$ (rain)

(c) Sediment supply conceptual model

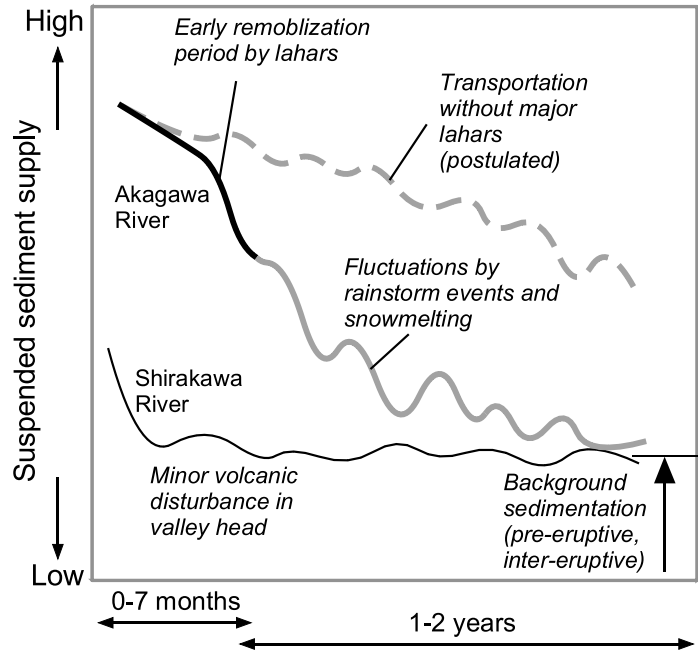

Time after the eruption

Fig. 2 Changes in electric conductivity (a) and suspended sediment concentration (b) in the Akagawa and Shirakawa rivers, and a conceptual diagram of the temporal variations in suspended sediment concentration transport (c)

delivery was controlled by snowmelt runoff that enhanced the erosion and reworking of eruptive and lahar material in the upstream part of the catchment rather than by further instances of mud slurries being expelled from the vents.

\section{Differences in post-eruption fluvial impact} between catchments

Despite the comparable catchment sizes of the Akagawa River and the Shirakawa River, there was a clear difference in sediment transport between the river systems after the eruption. The contrasts between the rivers can 
be summarized as follows: (1) No post-eruptive lahar deposits were detected upslope of the Shirakawa River valley (Kataoka et al. 2018). (2) High acidity, elevated EC, increased turbidity, and high suspended sediment concentration were observed in the Akagawa River, whereas values of these variables were low in the Shirakawa River. (3) High sediment concentration and transportation continued for a prolonged period in the Akagawa River. (4) Pyrite and pyrophyllite mineral grains were detected in the suspended sediment samples from the Akagawa River only.

Clearly, the differences between the two catchments can be attributed to the magnitude of volcanic disturbance in proximal areas from the eruption itself and post-eruptive lahar deposition. The head of the Akagawa catchment includes the 2014 vents and a zone of hydrothermal alteration; this area was directly affected by the 2014 eruption and received relatively thick pyroclastic fall deposits. Pyroclastic density current deposits were also emplaced, and a rain-triggered lahar developed in the upstream part of the Akagawa River valley. The absence of diagnostic mineral grains from the 2014 eruption in the Shirakawa River sediments and the low suspended sediment concentration immediately after the eruption indicate that the volume of pyroclastic density current deposits in the Shirakawa catchment was small, although details of their distribution and thickness are not well known (e.g., Yamamoto 2014). This finding suggests that a thin mantle of ashfall in the catchment could have resulted in limited sediment input to the river. Similar contrasts in sediment supply were observed in several catchments after the much larger eruption at Mount St. Helens in 1980. The catchments that were disturbed by pyroclastic flows, a debris avalanche, and lahars from Mount St Helens maintained high levels of sediment transport long after the eruption, whereas river catchments that were affected only by ashfall deposition returned to background sedimentation levels within a relatively short time span (Major et al. 2000).

The elevated EC values in the Akagawa River are attributed to the erosion, reworking, and entrainment of eruptive material and lahar deposits that contain minerals such as plagioclase feldspar and smectite (Kataoka et al. 2018). These minerals contain sodium and calcium, and previous studies have demonstrated that these elements show a positive correlation with EC values in leachate experiments on pyroclastic deposits (Genareau et al. 2016). Plagioclase is prone to chemical weathering (e.g., Nesbitt and Young 1996), and the acidity of the Akagawa River may have enhanced the dissolution of plagioclase grains. The mechanical fragmentation of eruptive material by the phreatic eruption at Ontake increased the bulk surface area of sediment, thus promoting interactions with water. Lower $\mathrm{pH}$ values in the Akagawa River together with a high sulfur content in suspended sediment (Tables 1 and 2) could be related to the dissolution of sulfide and sulfate minerals from the eruptive and lahar deposits, but the small temporal variations recorded during our 2-year monitoring period suggest that the low $\mathrm{pH}$ instead originated in the surface and subsurface water systems.

\section{Concluding remarks}

Our monitoring-based study shows that sustained transportation of suspended volcaniclastic sediment occurred in the Akagawa-Nigorigawa River system for at least 19 months following even the very small (VEI 1-2) Ontake eruption of 2014. Two post-eruptive lahars removed erupted material as a potential sediment source in the upstream part of the Akagawa catchment, and this remobilization contributed to a decline in sediment supply in the Akagawa River after the lahars (Fig. 2c). Remobilization of erodible volcanic material in river valleys during the early post-eruption phase of the 2000 eruption at Miyakejima was similarly a significant constraint on sediment discharge after that eruption (Yamakoshi et al. 2005). These findings suggest that a higher sediment supply will continue for a longer time period when only normal fluvial processes (without lahars) drive the erosion and transportation of eruptive material (Fig. 2c). Increased turbidity was observed during the snowmelt season and was associated with diurnal variations in flow discharge and with the occurrence of rainstorm events up to 19 months after the eruption. This finding indicates that precipitation and snowmelt during early spring can cause fluctuations in sediment delivery after the eruption of a seasonally snow-clad volcano.

The results of this study show that airborne and remote surveys of volcanic summit areas without field access can be evaluated by river monitoring at sites further downstream. As observed in the Akagawa River, a high rate of sediment delivery may reflect the distribution of primary deposits in upstream areas. This type of proximal area is difficult to access immediately after an eruption because of the high risk of volcanic activity and the challenging volcanic alpine terrain. The results presented here will contribute to predicting the responses of river systems and changes in river water characteristics following a future eruption at Ontake with similar size and characteristics to the 2014 eruption. 


\section{Additional file}

Additional file 1:A movie captured at 10-min intervals by a camera set in the Akagawa River from 22 to 30 April 2015 showing diurnal changes in water characteristics. The water was usually low and clear during mornings with a rise in discharge and turbidity (to a gray color) from approximately 2 p.m. to 5 p.m.

\section{Authors' contributions}

KSK contributed to writing the main part of the paper and compiling/interpreting the data. TM, KSK, TS, and TI engaged river water survey in the field. YN did geochemical analysis. All authors read and approved the final manuscript.

\begin{abstract}
Author details
${ }^{1}$ Research Institute for Natural Hazards and Disaster Recovery, Niigata University, Ikarashi 2-8050, Nishi-ku, Niigata 950-2181, Japan. ${ }^{2}$ Department of Geology, Shinshu University, 3-1-1 Asahi, Matsumoto, Nagano 390-8621, Japan. ${ }^{3}$ Faculty of Symbiotic Systems Science, Fukushima University, Kanayagawa 1, Fukushima 960-1296, Japan. ${ }^{4}$ Graduate School of Engineering, Kyoto University, Katsura, Kyoto 615-8530, Japan.
\end{abstract}

\section{Acknowledgements}

The authors are grateful to Kazumi Nakajima and his colleagues at Forestry Agency, Kiso Office, for giving helpful information to do fieldwork. Katsuhisa Kawashima (Niigata University), Akihiko Sasaki (Shinshu University), and Keisuke Suzuki (Shinshu University) provided meteorological data and discussion. Takuma Katori (Niigata University) helped us with mineral identification and XRD analysis. Keiko Yamagishi helped in sample preparation in the laboratory. This research is supported by an institutional research fund at the Research Institute for Natural Hazards and Disaster Recovery, Niigata University, in FY2014 (PI: KSK, co-PI:TM) and a collaborative research grant provided by the same institution in FY2014-2015 (PI:TS, co-PI: KSK). The authors appreciate and acknowledge two anonymous reviewers and Associate Editor Dr. Kazutaka Mannen for their thoughtful reading and constructive comments, which greatly improved the manuscript.

\section{Competing interests}

There are no competing interests in relation to the present research.

\section{Availability of data and materials}

Supporting data are available on the Web site of EPS.

\section{Consent for publication}

Not applicable.

\section{Ethics approval and consent to participate}

Not applicable.

\section{Funding}

This research is fully supported by the intermural research grant: the institutional research fund at the Research Institute for Natural Hazards and Disaster Recovery, Niigata University, in FY2014 (PI: KSK, co-PI: TM) and the collaborative research grant provided by the same institution in FY2014-2015 (PI: TS, CO-PI: KSK).

\section{Publisher's Note}

Springer Nature remains neutral with regard to jurisdictional claims in published maps and institutional affiliations.

Received: 31 March 2018 Accepted: 24 January 2019

Published online: 07 February 2019

\section{References}

Blong R (1984) Volcanic hazards: a sourcebook on the effects of eruptions. Academic Press, Samford, p 424p

Genareau K, Cronin SJ, Stewart C, Bhattacharyya S, Donahoe R (2016) Posteruptive impacts of pyroclastic deposits from basaltic andesite stratovolcanoes on surface water composition. J Geophys Res Biogeosci 121:1275-1287

Gran KB, Montgomery DR, Halbur JC (2011) Long-term post-eruption elevated sediment yields at Mount Pinatubo, Philippines. Geology 39:367-370

Kaneko T, Maeno F, Nakada S (2016) 2014 Mount Ontake eruption: characteristics of the phreatic eruption as inferred from aerial observations. Earth Planets Space 68:72. https://doi.org/10.1186/s40623-016-0452-y

Kataoka KS, Matsumoto T, Saito T, Kawashima K, Nagahashi Y, lyobe T, Sasaki A, Suzuki K (2018) Lahar characteristics as a function of triggering mechanism at a seasonally snow-clad volcano: contrasting lahars following the 2014 phreatic eruption of Ontake Volcano, Japan. Earth Planets Space 70:113. https://doi.org/10.1186/s40623-018-0873-x

Kristmannsdóttir H, Björnsson A, Pálsson S, Sveinbjörnsdóttir ÁE (1999) The impact of the 1996 subglacial volcanic eruption in Vatnajökull on the river Jökulsá á Fjöllum, North Iceland. J Volcanol Geotherm Res 92:359-372

Maeno F, Nakada S, Oikawa T, Yoshimoto M, Komori J, Ishizuka Y, Takeshita Y, Shimano T, Kaneko T, Nagai M (2016) Reconstruction of a phreatic eruption on 27 September 2014 at Ontake volcano, central Japan, based on proximal pyroclastic density current and fallout deposits. Earth Planets Space 68:82. https://doi.org/10.1186/s40623-016-0449-6

Major JJ (2004) Posteruption suspended sediment transport at Mount St. Helens: decadal-scale relationships between landscape adjustments and river discharges. J Geophys Res 109(F1):F01002

Major JJ, Yamakoshi T (2005) Decadal-scale change of infiltration characteristics of a tephra-mantled hillslope at Mount St. Helens, Washington. Hydrol Processes 19:3621-3630

Major JJ, Pierson TC, Dinehart RL, Costa JE (2000) Sediment yield following severe volcanic disturbance-a two-decade perspective from Mount St. Helens. Geology 28:819-822

Minami Y, Imura T, Hayashi S, Ohba T (2016) Mineralogical study on volcanic ash of the eruption on September 27, 2014 at Ontake volcano, central Japan: correlation with porphyry copper systems. Earth Planets Space 68:67. https://doi.org/10.1186/s40623-016-0440-2

Nesbitt HW, Young GM (1996) Petrogenesis of sediments in the absence of chemical weathering: effects of abrasion and sorting on bulk composition and mineralogy. Sedimentology 43:341-358

Newhall CG, Self S (1982) The volcanic explosivity index (VEI) an estimate of explosive magnitude for historical volcanism. J Geophys Res 87:1231-1238

Ogawa Y, Daimaru H, Shimizu A (2007) Experimental study of post-eruption overland flow and sediment load from slopes overlain by pyroclasticflow deposits, Unzen volcano, Japan. Géomorphol Relief Proc Environ 3:237-246

Oikawa T, Suzuki Y, Chiba T (2014) Eruption history and 2014 eruption of Ontake volcano. Kagaku 84:1218-1225 (in Japanese)

Oikawa T, Yoshimoto M, Nakada S, Maeno F, Komori J, Shimano T, Takeshita Y, Ishizuka Y, Ishimine $Y$ (2016) Reconstruction of the 2014 eruption sequence of Ontake Volcano from recorded images and interviews. Earth Planets Space 68:79. https://doi.org/10.1186/s40623-016-0458-5

Pierson TC, Major JJ (2014) Hydrogeomorphic effects of explosive volcanic eruptions on drainage basins. Ann Rev Earth Planet Sci 42:469-507

Sasaki H, Chiba T, Kishimoto H, Naruke S (2016) Characteristics of the syneruptive-spouted type lahar generated by the September 2014 eruption of Mount Ontake, Japan. Earth Planets Space 68:141. https://doi. org/10.1186/s40623-016-0516-z

Stewart C, Johnston DM, Leonard GS, Horwell CJ, Thordarson T, Cronin SJ (2006) Contamination of water supplies by volcanic ashfall: a literature review and simple impact modelling. J Volcanol Geotherm Res 158:296-306 
Takarada S, Oikawa T, Furukawa R, Hoshizumi H, Itoh J, Geshi N, Miyagi I (2016) Estimation of total discharged mass from the phreatic eruption of Ontake Volcano, central Japan, on September 27, 2014. Earth Planets Space 68:138. https://doi.org/10.1186/s40623-016-0511-4

Takase T, Nagahashi Y (2007) Determination of major and trace elements in rock samples by $X$-ray fluorescence spectrometry - comparison with a glass beads method and a powder pellets method. J Center Reg Aff Fukushima Univ 19:32-47 (in Japanese with English abstract)
Yamakoshi T, Doi Y, Osanai N (2005) Post-eruption hydrology and sediment discharge at the Miyakejima volcano, Japan. Z Geomorphol N F Suppl 140:55-72

Yamamoto T (2014) The pyroclastic density currents generated by the September 27, 2014 phreatic eruption of Ontake Volcano, Japan. Bull Geol Surv Japan 65:117-127

\section{Submit your manuscript to a SpringerOpen ${ }^{\circ}$ journal and benefit from:}

- Convenient online submission

- Rigorous peer review

- Open access: articles freely available online

- High visibility within the field

- Retaining the copyright to your article

Submit your next manuscript at $\boldsymbol{\nabla}$ springeropen.com 